\title{
Response to Magnesium of Intensively Managed Sun-grown Coffee
}

\author{
E. Hernández Medina, Fernando Abruña, and R. del Talle ${ }^{1}$
}

\section{INTRODUCTION}

In some coffee regions of Puerto Rico certain nutritional deficiencics have been observed in sun-grown coffee. From the appearance of the leaves these nutritional disorders are similar to those observed in coffee trees in some countries of Central and South America caused by lack of magnesium, zinc, or iron $(4,7,8,9,11) .{ }^{2}$ These nutritional deficiencies, especially those of magnesium and zinc, have been observed mainly on unshaded coffee grown in the vicinity of Jayuya and Lares and, to a lesser extent, in coffee farms near Adjuntas.

To determine the extent to which the above-mentioned nutritional deficiencies might be affecting coffee growth and yields, several field trials were established at different sites of the Coffee Region of the Island.

The information presented herein deals with the results so far obtained in one of the field trials where magnesium was used to ascertain the effectiveness of this nutrient in correcting magnesium deficiency and in increasing coffee yields.

\section{EXPERIMENTAL PROCEDURE}

The experiment was initiated in the vicinity of Jayuya at an elevation of approximately 2,500 feet. The soil used was Los Guineos clay with a $\mathrm{pH}$ range between 4.9 and 5.4, an exchange capacity of 16 meq., and 4 meq. of exchangeable bases per $100 \mathrm{gm}$. of soil. This soil has good drainage and good physical condition (12).

Arabica coffee of the Bourbon variety was used in the experiment, which followed a paired-plot design with four treatments and six replications. Individual plots consisted of 12 trees, 6 trees in each of 2 rows of a hedge, or 1,350 trees per acre.

Fertilizer treatments consisted of four levels of magnesium at the following rates: $0,30,60$, and 90 pounds per acre. Commercial fertilizer (10-6-20) was applied in all treatments at the rate of 20 hundredweights per acre yearly in three equal applications, in the spring, summer, and autumn.

${ }_{1}$ Agronomist, Agricultural Experiment Station, Mayagüez Campus, University of Puerto Rico, Río Piedras, P.R.; Soil Scientist, Soil and Water Conservation Research Division, Agricultural Research Service, USDA, stationed at Río Piedras, P.R.; Research Assistant, Agricultural Experiment Station, Mayagüez Campus, University of Puerto Rico, Río Piedras, P.R.

2 Numbers in parentheses refer to Literature Cited, pp. 193-4. 
Leaf-miner and other insects were controlled by spraying with a mixture of $11 / 2$ pound of 15 -percent Parathion ${ }^{3}$ and $1 / 2$ gallon of 15 -percent Dieldrin per acre.

In the summer and autumn of 1962, leaf samples were taken from the trees of each replication of each treatment for chemical determination of magnesium. The third or fourth pair of leaves from lateral branches were taken for this purpose (5). Magnesium was determined according to the Parks et al. (10) procedure in an effort to discover possible correlations between leaf-nutrient content and coffee yields.

\section{EXPERIMENTAL RESULTS}

\section{MAGNESIUM-DEFICIENCY SYMPTOMS}

As observed in this experimeut, and in others concurrently running, a deficiency of magnesium produces a marked and characteristic chlorosis in the older leaves. Very narrow bands of green tissue a few millimeters in width remain along the midrib and principal lateral veins. The chlorosis starts right at the edge of the green tissue of the midrib and gradually extends outwards, sometimes covering the leaf margin. The chlorotic area is of a light-green color, or more typically, dull bronze or yellow-ochre. In extreme cases of deficiency only part of the central section of the leaf remains green, a long wedge-shaped pattern starting at the point of insertion of the petiole. These symptoms are more pronounced when the coffee trees are in full bearing. In the long run a deficiency of magnesium brings about shedding of the affected leaves from the coffee trees. This is in agreement with observations made elsewhere $(8,6,8)$ (fig. 1), shows typical magnesium-deficiency symptoms as observed in coffee trees.

FIELD DATA

\section{Tree growth}

Periodic observations on tree growth revealed that magnesium application was quite effective in controlling leaf magnesium deficiency (fig. 2).

\section{Coffee yields}

The effect of magnesium applications on yields of market coffee for 3-yearold trees are presented in table 1. A study of these data reveals that there was a significant yield increase of marketable coffee in favor of magnesiumtreated trees at the three levels of magnesium tested. The increase in yield

3 Trade names are used in this publication solely for the purpose of providing specific information. Mention of a trade name does not constitute a guarantee, warranty, or endorsement by the Agricultural Experiment Station indicating or implying superiority to other similar products not mentioned. 

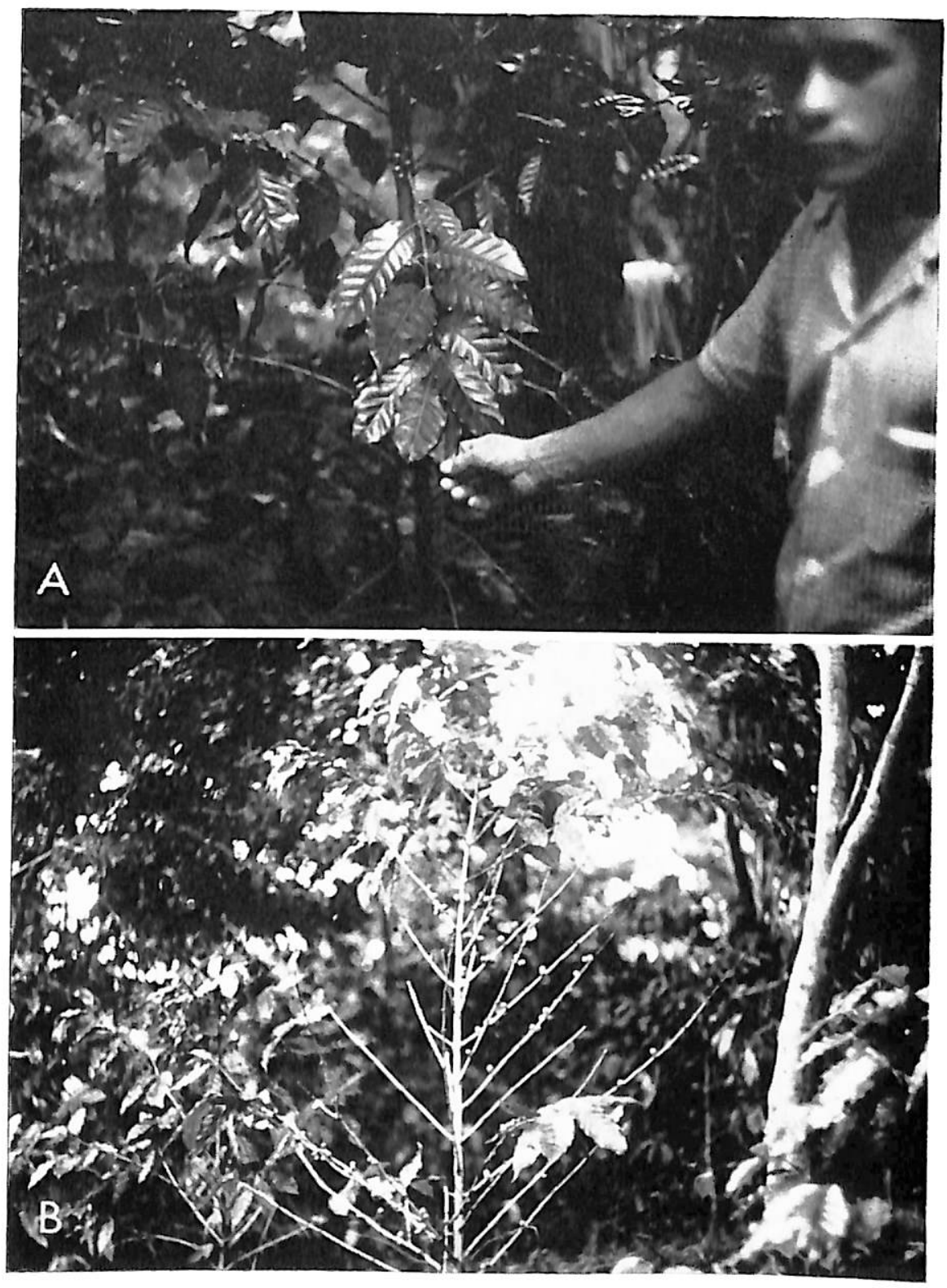

FIg. 1.-A, Magnesium-deficient coffee tree. Magnesium deficiency was characterized by a marked and characteristic chlorosis of the older leaves. Very narrow bands of green tissue remained among the midrib and principal lateral veins. The chlorotic area was light-green in color, or more typically dull bronze or yellow-ochre. $B$, Coffee tree heavily defoliated as a result of magnesium deficiency. 
of these trees over the check trees for each increment of magnesium was of the following magnitude: $6.13,7.72$, and 8.63 hundredweights per acre, respectively. This is equivalent to a 35.8-, 45.0-, and 50.4-percent increase

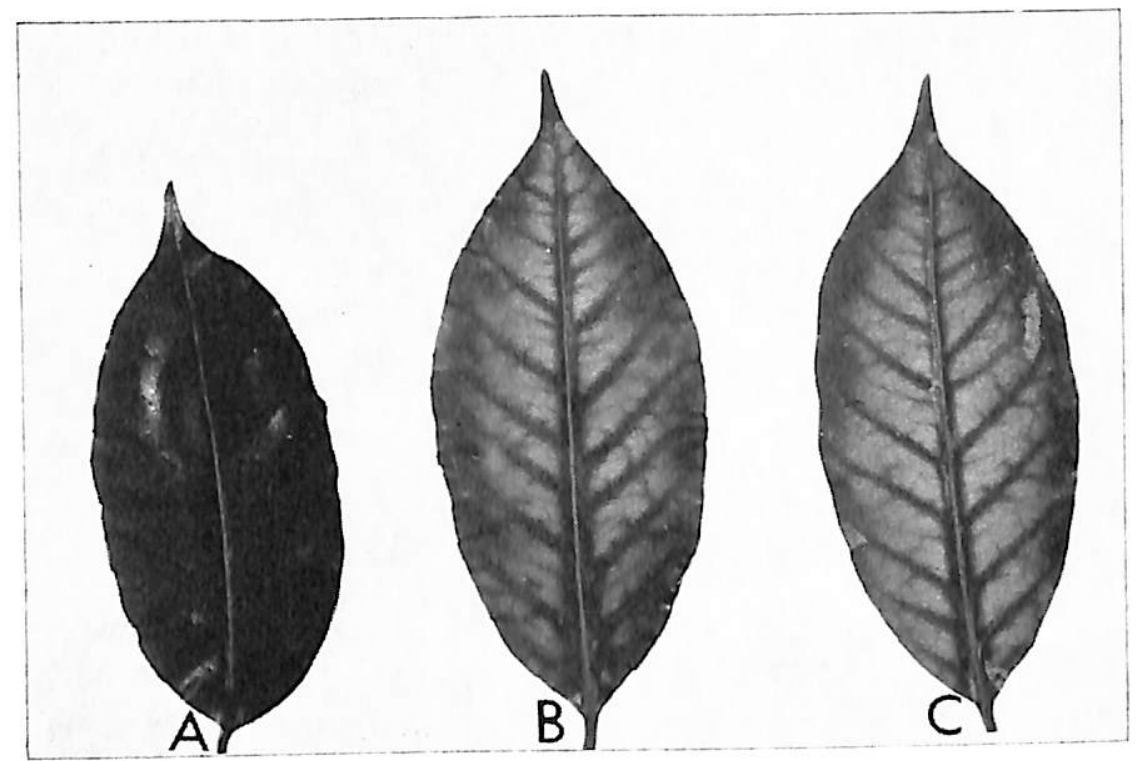

Fig. 2.-A, Leaf from a coffee tree that received magnesium; leaf was dark-green in color and healthy; $B$ and $C$, leaves from a coffee tree not receiving magnesium showing typical magnesium-deficiency symptoms.

TABLE 1.-Effect of magnesium on yields and foliar composition of sun-grown coffee on Los Guineos clay, Jаyиya, P.R.

\begin{tabular}{c|c|c|c|c}
\hline & & & \multicolumn{2}{|c}{ Leaf $\mathrm{Mg}$ content } \\
\cline { 3 - 5 } Treatment No. & Magnesium & Yields of market cofiee & $\begin{array}{c}\text { Summer } \\
\text { samples }\end{array}$ & Fall samples \\
\cline { 3 - 5 } & & & Percent & Percent \\
\cline { 3 - 5 } & Lb./acre & 17.14 & 0.14 & 0.15 \\
2 & 0 & $23.27^{1}$ & .26 & .35 \\
3 & 30 & $24.86^{1}$ & .27 & .38 \\
4 & 60 & $25.77^{1}$ & .31 & .42 \\
\hline
\end{tabular}

1 Significant yield differences over the check.

over the nontreated plots, respectively. However, no significant yield differences were attained between trees differentially treated with magnesium. Figure 3 illustrates graphically the effect of magnesium on coffee yields, 


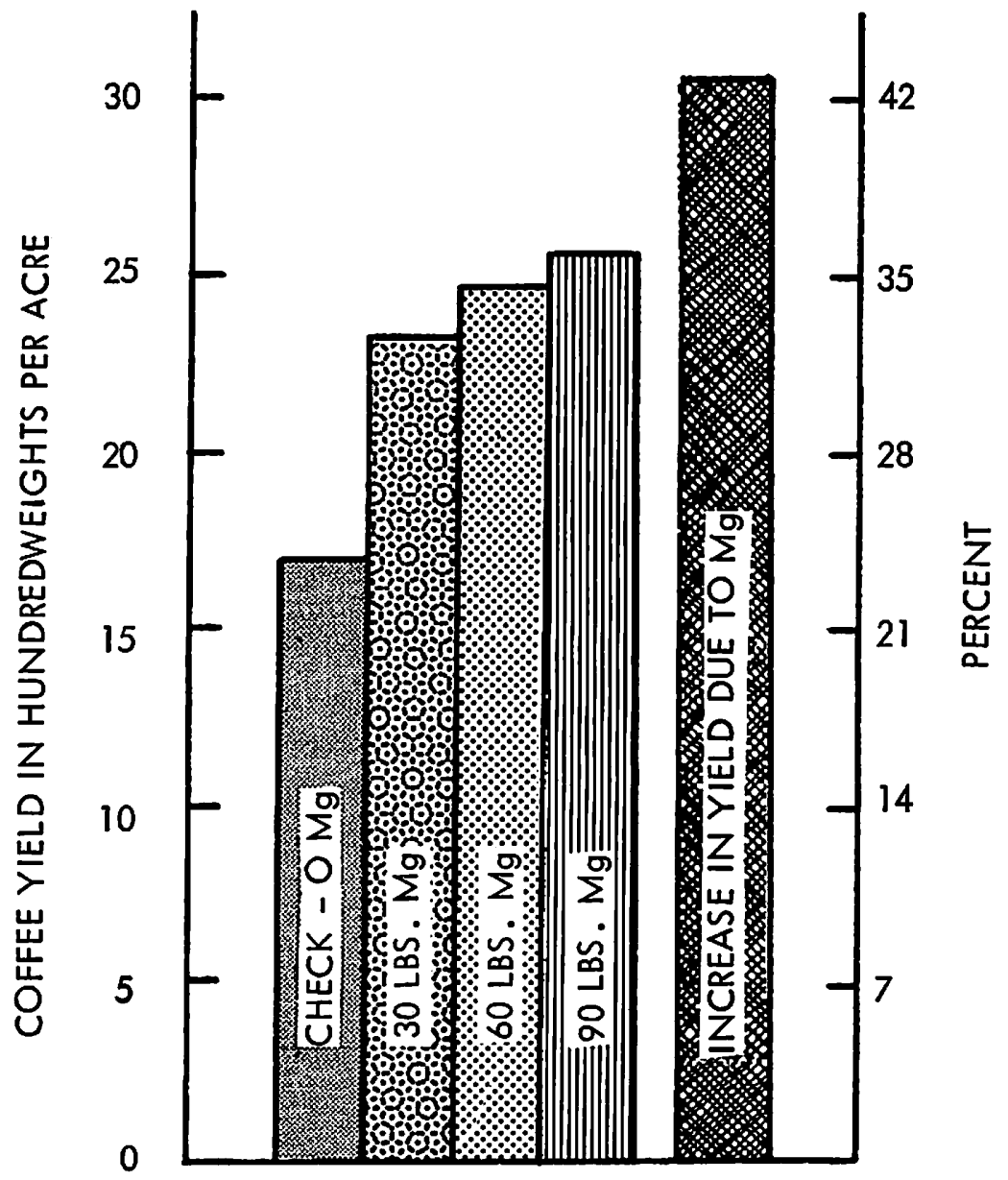

FI(i. 3.-Coffee yields as affected by magnesium applications on Los (iuineos clay. Dark bar at right indicates percent age increase in yield in favor of coffee trees which received magnesium as compared with those not receiving magnesium.

and the percentage increase in yield (black bar) of trees supplied with magnesium.

\section{LEAF MAGNESIUM AND REGRESSION ANALYSES}

Table 1 also shows the magnesium content of the coffee leaves collected at two different seasons of the year from trees supplied and trees not supplied with magnesium. It appears from the chemical values obtained that there is a close relationship hetween leaf magnesium and coffee yield. Capó 
and Samuels' mathematical equation, $Y r=A+B$ arc-tangent-percent $\mathrm{Nu}$ (2) was used in an effort to explain the above-mentioned nutrientyield relation, on both sets of samples. This equation was fitted to 24 individual values the means of which are given by treatments in table 1 . The

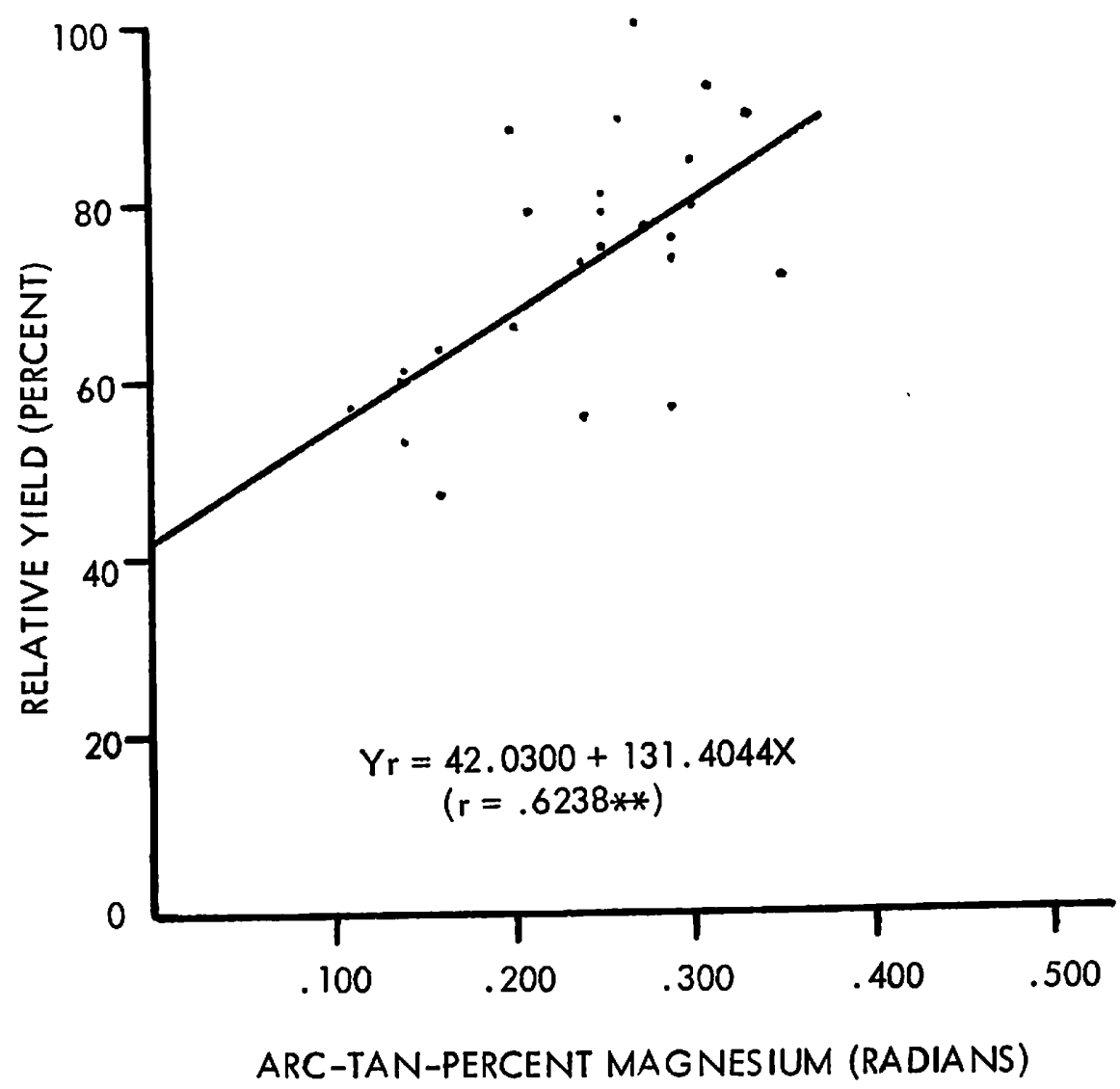

Fic. 4--Regression of relative yield of coffee on arc-tangent-percent magnesium as determined on summer leaf samples.

formula obtained relating yield and leaf-nutrient content of the summer leaf samples is as follows:

$$
Y r=42.0300+131.4044 \text { (arc-tan1-percent } \mathrm{Mg} \text { ) }
$$

The statistical evaluation of the fit of this equation indicated that the regression of relative yield on arc-tangent-percent magnesium was significant at the 1-percent level with a coefficient of determination of 39 percent.

For the fall leaf samples, the regression equation obtained relating yield 
and nutrient composition of the coffee leaf is as follows:

$$
Y r=45.0149+90.7236(\text { arc-tan-percent } \mathrm{Mg})
$$

As in the preceding case, the statistical evaluation of the fit of the equation showed that the regression of relative yield on arc-tan-percent $\mathrm{Mg}$

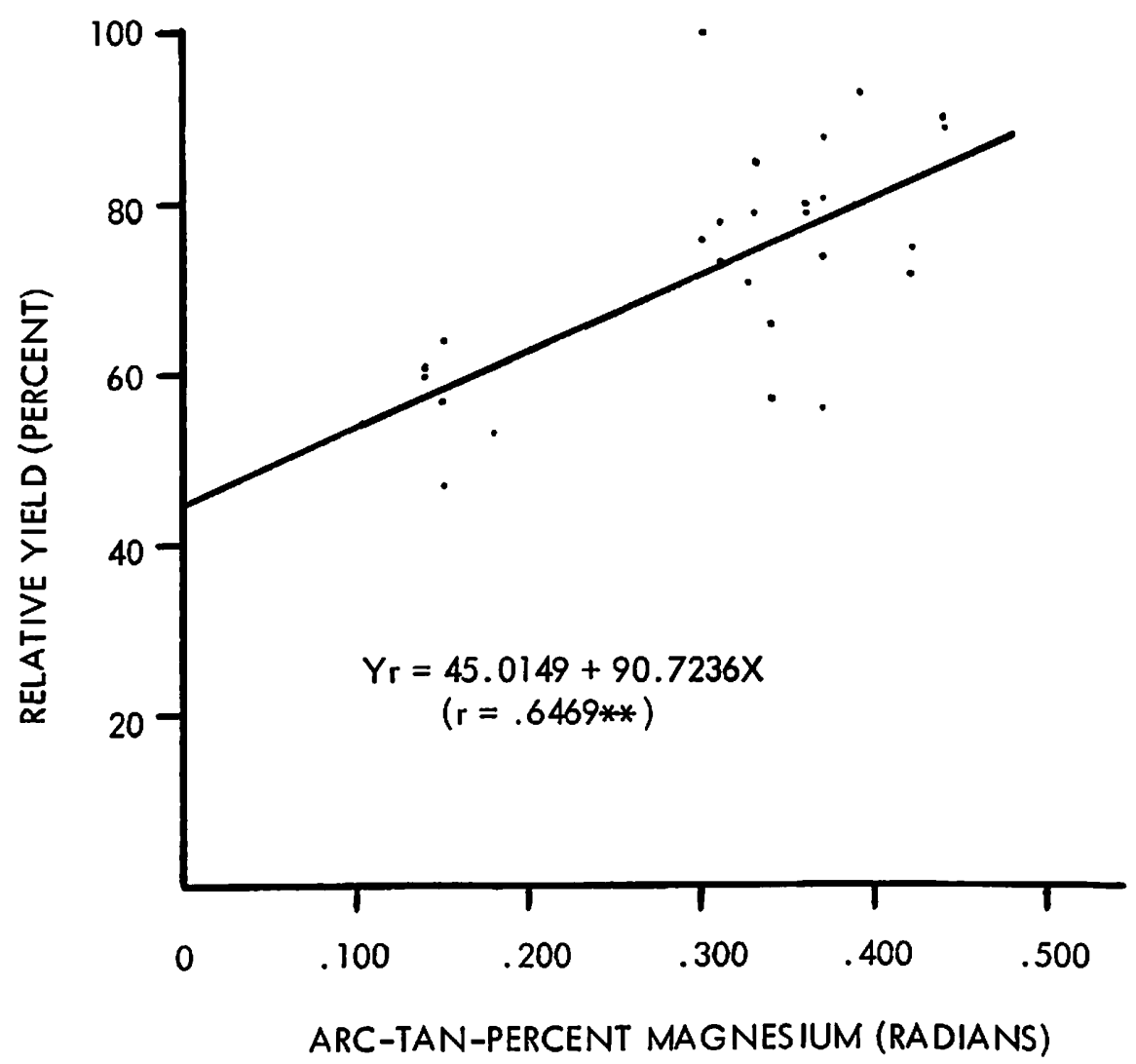

FI(i. 5.-Regression of relative yield of coffee on arc-tangent-percent magnesium as determined on fall leaf samples.

was also highly significant with a coefficient of determination of 42 percent. Thus, it is evident that a somewhat better correlation between leaf composition and yield was ascertained with the leaf samples collected in the fall. These nutrient-yield relations are illustrated graphically in figures 4 and 5 .

\section{DISCUSSION AND CONCLUSIONS}

An overall examination of the data presented in this paper underlines the need of incorporating magnesium in the NPK fertilizer mixture for 
increasing coffee yields in Los Guineos clay, and/or similar related soils of the Jayuya and other sites of similar environmental conditions. It was found that the leaf-magnesium content of the coffee trees not supplied with magnesium was within the insufficiency range, while that of trees supplied with this nutritive element was within the sufficiency range (7).

The data reported herein in regard to the beneficial effect of magnesium on coffee yields are in disagreement with the results obtained by Abruna et al. (1), which showed a lack of response to magnesium application by their coffee trees grown in the same Los Guineos clay. This lack of agreement is attributed to the fact that, in their expcriment, limestone containing 1-percent magnesium was used at the rate of 4 tons per acre in a 3year period. Thus, the lime material supplied 80 pounds of magnesium per acre, sufficient to take care of any soil-magnesium deficit.

It was of interest to discover also that as low as 30 pounds of elemental magnesium per acre was sufficient to boost coffee yields significantly over no-magnesium applications. Since it was found that there were no significant differences in yield between 30 pounds of magnesium per acre and the higher rates used, it may be concluded that 30 pounds of this nutrient per acre is adequate to produce good yields of coffee in Los Guineos clay.

Based on the correlation studies between leaf-magnesium content and relative yields, it may be also concluded that the percentage magnesium content of the coffee leaf can be used as an index to predict the relative yield of coffee.

The outstandingly beneficial effect so far obtained with magnesium on such crops as pineapples, plantains and, at present, with coffee, merits further studies with this nutrient which might become an important item in the fertilization of our tropical crops.

\section{SUMMARY}

The effect of magnesium on the yield of coffee grown in the acid Los Guineos clay was investigated and the following conclusions were drawn from the results:

1. Magnesium applications to coffee trees controlled leaf-magnesium deficiency.

2. Magnesium was responsible for significantly increasing coffee yields. Coffee trees supplied with magnesium produced, on the average, 7.5 hundredweights more marketable coffee per acre than the trees not receiving magnesium.

3. Highest coffee yields were associated with high leaf-magnesium contents.

4. Highly significant correlations were found between relative yields and leaf-magnesium values in both summer and fall leaf samples. 
5. The data indicate that magnesium content of coffee leaves can be used to predict relative yields.

\section{RESUMEN}

Los resultados del estudio para determinar el efecto del magnesio sobre el rendimiento del café sembrado en un suelo de tipo Los Guineos arcilloso sugieren las conclusiones siguientes:

1. Las aplicaciones de magnesio a los cafetos corrigieron la deficiencia de magnesio en el suelo.

2. El magnesio indujo un aumento significativo en el rendimiento de los cafetos que recibieron las aplicaciones, los cuales produjeron, aproximadamente, $7 . \overline{5}$ quintales más de café por acre que los que no recibieron dicho nutrimento.

3. Los rendimientos máximos guardaron relación con los altos contenidos de magnesio en la hoja.

4. Se obtuvieron correlaciones altamente significativas entre el rendimiento y el contenido de magnesio en las hojas de las muestras recolectadas en el verano y el otoño.

5. Los datos obtenidos indican que el contenido de magnesio en las hojas recolectadas en el verano y el otoño puede servir de índice para estimar los rendimientos relativos del café.

\section{LITERATURE CITED}

1. Abruña, F., Vicente Chandler, J., Becerra, L. A., and Bosque Lugo, R., Effects of liming and fertilization on yields and foliar composition of high-yielding sun-grown coffee in Puerto Rico, J. Agr. Univ. P.R. 49 (4): 413-28, 1965.

2. Capó, B. G., and Samuels, $G$., The development of a mathematical concept to interpret the relation between plant composition and crop yield, J. Agr. Univ. P.R. 37 (t): 249-64, 1953.

3. Cibes, H., and Samuels, (i., Mineral-deficiency symptoms displayed by coffee trees grown under controlled conditions, Agr. Expt. Sta., Univ. P.R. Tech. Paper 14, 1955.

4. Franco, C. M., and Mendes, H. C., Sintomas de deficiencias minerais no caffeeiro, Braganlia, 9: 165-73, 1949.

5. Lott, W. L., Nery, J. P., (iallo, J. R., and Medcalf, J. C., Leaf analysis technique in coffee research, Ibec. Resenrch Institute Bull. 9, 1-26, 1956.

6. Jouc, A., Studies on the inorganic nutrition of the coffee tree in the Ivory Coast, Centre de Recherches Agronomiques, Spec. Bull. 1-68, 1957.

7. Malavolta, E., Haag, II. P., Mello, F. A. F., and Brasil Sobro, M. O. C., On the mineral nutrition of some tropical crops, Int. Potash Inst., Berne, Switzerland, 1962.

8. Muller, L. E., Algunas deficiencias minerales comunes en el cafeto (Coffea arabica L.) Inst. Interam. Cienc. Agr. (Turrialba, Costa Rica), Bol. Tech. $4,1-41,1959$.

9. - , Nut rición mineral del cafó, II l)etección y control de deficiencias de ele- 
194 JOURNAL OF AGRICULTURE OF UNIVERSITY OF PUERTO RICO

mentos escenciales, Inst. Interam. Cienc. Agric. (Turrialba, Costa Rica), Reimpreso de "Progresos en la Técnica de la Producción de Café," 97-109, 1958.

10. Parks, R. Q., Hood, S. L., Hurwitz, Ch., and Ellis, H. G., Quantitative chemical microdeterminations of 12 elements in plant tissues, Int. and Eng. Chem. Anal. Ed. 15 (8): 527-33, 1943.

11. Pérez, S. MI. V., Algunas deficiencias minerales del cafeto en Costa Rica, Min. de Agric. e Indus, de Costa Rica, Inform Núm. 2, 1-27, 1957.

12. Roberts, R. C., Soil Survey of Puerto Rico, USDA, Bureau of Plant Industry in cooperation with the Univ. P.R., Agr. Expt. Sta., Ser. 1936, (8) p. 503, Jan. 1942. 